\title{
Aging, Resistance Training, and Diabetes Prevention
}

\author{
Kyle D. Flack, ${ }^{1}$ Kevin P. Davy, ${ }^{1}$ Matthew W. Hulver, ${ }^{1}$ Richard A. Winett, ${ }^{2}$ \\ Madlyn I. Frisard, ${ }^{1}$ and Brenda M. Davy ${ }^{1}$ \\ ${ }^{1}$ Department of Human Nutrition, Foods and Exercise, 221 Wallace Hall (0430), Virginia Tech, Blacksburg, VA 24061, USA \\ ${ }^{2}$ Center for Research in Health Behavior, 460 Turner Street, Suite 203, Virginia Tech, Blacksburg, VA 24061, USA
}

Correspondence should be addressed to Brenda M. Davy, bdavy@vt.edu

Received 1 September 2010; Accepted 5 November 2010

Academic Editor: Ben Hurley

Copyright () 2011 Kyle D. Flack et al. This is an open access article distributed under the Creative Commons Attribution License, which permits unrestricted use, distribution, and reproduction in any medium, provided the original work is properly cited.

\begin{abstract}
With the aging of the baby-boom generation and increases in life expectancy, the American population is growing older. Aging is associated with adverse changes in glucose tolerance and increased risk of diabetes; the increasing prevalence of diabetes among older adults suggests a clear need for effective diabetes prevention approaches for this population. The purpose of paper is to review what is known about changes in glucose tolerance with advancing age and the potential utility of resistance training (RT) as an intervention to prevent diabetes among middle-aged and older adults. Age-related factors contributing to glucose intolerance, which may be improved with RT, include improvements in insulin signaling defects, reductions in tumor necrosis factor- $\alpha$, increases in adiponectin and insulin-like growth factor- 1 concentrations, and reductions in total and abdominal visceral fat. Current RT recommendations and future areas for investigation are presented.
\end{abstract}

\section{Introduction}

With the aging of the baby boom population and an increased life expectancy, individuals aged 65 years or older are the fastest growing segment of our population [1]. Increases in the number of individuals aged $65+$ years will increase demands on health care and health care costs, which could lead to inadequate public resources and less care for the aged [1]. Chronic conditions such as diabetes exert a profound economic impact on our nation; this disease and its associated comorbidities are a major cause of disability and death [2]. In 2007, the total estimated cost of diabetes was $\$ 174$ billion, which included $\$ 116$ billion in medical costs and $\$ 58$ billion in reduced productivity [3].

Total diabetes prevalence (undiagnosed and diagnosed) is currently estimated to be $14 \%$ of the U.S adult population [4] and is highest in those aged $\geq 65$ years [2]. Prediabetes, that is, impaired fasting glucose (IFG; $100 \mathrm{mg} / \mathrm{dl}$ $(5.6 \mathrm{mmol} / \mathrm{l})-125 \mathrm{mg} / \mathrm{dl}(6.9 \mathrm{mmol} / \mathrm{l}))$, or impaired glucose tolerance (IGT; 2-h plasma glucose $140 \mathrm{mg} / \mathrm{dl}(7.8 \mathrm{mmol} / \mathrm{l})$ $199 \mathrm{mg} / \mathrm{dl}(11.0 \mathrm{mmol} / \mathrm{l}))$ [5] is also becoming more prevalent in the United States [6]. Individuals with prediabetes are at increased risk for developing diabetes, with the progression of diabetes within 6 years of those with IFG and IGT being $65 \%$, as compared to a $5 \%$ progression rate for those with normal blood glucose levels [7]. Recent estimates indicate that by the year 2050, diabetes prevalence could be as high as $33 \%$ [4]. The increased prevalence of diabetes among older adults, coupled with the aging of our population, suggests a clear need for effective diabetes prevention strategies. The purpose of the present paper is to review what is currently known about changes in glucose tolerance with advancing age, and the potential utility of resistance training (RT) as an intervention to prevent diabetes among middle-aged and older adults. Current RT recommendations and areas for future investigation are also presented.

\section{Aging: Changes in Body Composition and Glucose Tolerance}

2.1. Aging and Sarcopenia. Aging brings about a decline in skeletal muscle mass termed sarcopenia [8-10]. Muscle mass declines at a rate of $3-8 \%$ each decade after the age of 30 [11]. This loss of muscle mass increases the risk of developing 
glucose intolerance and diabetes due to the fact that muscle tissue is the primary site of glucose disposal [12-14]. There are many potential causes of sarcopenia including a reduction in muscle cell number through apoptosis, loss of motorneurons, and a reduction in calcium pumping activity. In addition, a decrease in the muscle twitch time and force is experienced, which can be considered a cause or an effect of sarcopenia $[9,15-17]$. Increases in inflammatory cytokines and oxidative stress may also contribute to sarcopenia [18]. Other consequences of this decline in muscle mass include reduced muscle strength, reduced resting metabolic rate, reduced lipid oxidative capacity, and increased adiposity (reviewed in [8]). Many clinical studies have shown that increasing lean body mass (primarily muscle mass) parallels the improvements in glucose tolerance seen with resistance training among older adults [19-31]. However, others have suggested that the prevalence of glucose intolerance in older individuals is not a direct reflection of one's lean body mass, but a result of age-associated increases in abdominal fat [32-34]. Although lean mass may not be the most robust predictor of glucose tolerance, the results of numerous clinical trials suggest that increases in lean body mass with RT are associated with improvements in glucose tolerance [19-31]. Therefore, increasing lean mass regardless of baseline levels should improve glucose tolerance and insulin-resistance, which may be an important strategy to combat the age-related increases in insulin-resistance and glucose intolerance.

2.2. Aging and Body Fat Distribution. Along with reductions in lean mass, older individuals often experience increases in adipose tissue [35-37]. Aging is strongly associated with increases in body weight and body fatness $[38,39]$. Based on the 2007-2008 National Health and Nutrition Examination Survey (NHANES), 78.4\% of men and 68.6\% of woman $\geq 60$ years were considered overweight or obese $\left(\mathrm{BMI} \geq 25 \mathrm{~kg} / \mathrm{m}^{2}\right)$. This represents the highest prevalence of overweight or obesity across all age groups [40]. This could partially be due to reductions in physical activity; for example, older adults average $37 \%$ fewer steps per day when compared to younger adults, and perform significantly less moderate to vigorous physical activity [41]. Older adults often do not achieve the recommended amount of physical activity (i.e., $\geq 30$ minutes of moderate physical activity on five or more days/week) proposed by organizations including the World Health Organization, Center for Disease Control and Prevention, Health Canada, and the Department of Health and Ageing [41].

Body fat accumulation is associated with an increased risk of premature mortality and morbidity [39], as well as hyperinsulinemia and glucose intolerance [38, 42]. Older individuals also demonstrate changes in body fat distribution, with increasing levels of upper body fat [35-37]. This increase in upper body fat (specifically abdominal visceral fat) has been linked to glucose intolerance and diabetes [43-45], and abdominal visceral fat is an independent predictor of glucose intolerance [34, 45]. This adipose tissue depot is sensitive to lipolytic stimuli, and in obese states may lead to increased circulating free fatty acid (FFA) concentrations [46, 47]. Visceral fat lipolysis may be responsible for $5-10 \%$ of circulating FFAs in lean individuals, while this value may increase to $20-25 \%$ in obese individuals $[47,48]$. However, upper body, nonvisceral fat is the primary contributor to FFA concentrations [48]. Increased FFA concentrations have been implicated in the development of insulin-resistance and metabolic inflexibility [47-50].

\section{Aging and Glucose Intolerance: Potential Contributing Factors}

Although factors such as a reduction in lean body mass, physical inactivity, obesity, and changes in fat distribution may contribute to glucose intolerance, age appears to be an independent determinant of impaired glucose tolerance $[42,51,52]$.

3.1. Insulin Signaling within Skeletal Muscle. Insulin's effects on peripheral tissues (i.e., skeletal muscle, adipose tissue) involve a complex framework of signaling pathways that result in the translocation of GLUT4 transporters to the cell surface, which are responsible for the transport of glucose across the plasma membrane into the target cell [53]. An alteration in any of the related pathways reduces insulin's effectiveness and leads to the insulin-resistance and glucose intolerance associated with advancing age. The insulin signaling process is complex and not fully understood (reviewed in $[53,54]$ ). Both diabetes and ageassociated declines in glucose tolerance are hallmarked by a decreased uptake of glucose by peripheral tissues, primarily skeletal muscle. The age-associated reduction in glucose uptake is not due to impaired insulin binding, but instead to a defect in the postreceptor intracellular insulin signaling pathway $[53,55-57]$. This defect has not been fully elucidated; however, a reduction in the number of insulin-stimulated glucose transport units occurs with aging [56]. Thus, fewer GLUT-4 transporters and/or postreceptor defects in the insulin signaling cascade results in insulin-resistance. Exercise-induced, contraction-mediated GLUT4 translocation to the muscle membrane is independent of insulin and occurs via an alternative mechanism (reviewed in [58]). Importantly, older adults with diminished glucose tolerance do not demonstrate a decline in exercise-induced contractile-mediated GLUT4 translocation [59].

3.2. Aging and Pancreatic Beta Cell Function. Insulin secretion decreases at a rate of $0.7 \%$ per year with advancing age, and is accelerated twofold in individuals with glucose intolerance [60]; yet it is uncertain the extent to which reduced insulin secretion is due to $\beta$-cell dysfunction or reduced $\beta$-cell mass [60]. Individuals with glucose intolerance demonstrate a $50 \%$ reduction in $\beta$-cell mass [61], which may be attributed to increased $\beta$-cell apoptosis. The aging of $\beta$-cells appears to decrease proliferation and increase sensitivity to hyperglycemia-induced apoptosis [62]. 
Diminished $\beta$-cell function has been reported among individuals with glucose intolerance, which decreases as fasting plasma glucose concentrations increase [63]. Therefore, a combination of $\beta$-cell dysfunction and $\beta$-cell apoptosis may contribute to age-related declines in glucose tolerance.

3.3. Aging and Mitochondrial Function. A reduction in mitochondrial function may also contribute to age-related declines in glucose uptake [64-67], possibly arising from increases in mitochondrial DNA deletions and mutations $[67,68]$. This may lead to a $40 \%$ decrease in mitochondrial oxidative metabolism in older adults compared to younger individuals [66]. Specifically, cytochrome c oxidase gene expression and enzyme activity are reduced in aged skeletal muscle [67]. This mitochondrial dysfunction contributes to the decline in physical fitness and oxidative capacity older adults may experience $[67,69]$. Insulin resistance is related to increased plasma FFA concentrations and enhanced FFA influx into skeletal muscle [66, 70-72]; decreased mitochondrial oxidative capacity may cause intramyocellular accumulation of fatty acid metabolites such as fatty acyl coenzyme-A, diacylglycerol, and ceramide to accumulate and produce insulin-resistance through serine kinase activation $[65,66,72]$. Serine kinases impede insulin signaling by reducing IRS phosphorylation $[64,65,72]$ which leads to a decline in insulin-stimulated GLUT4 translocation and impaired skeletal muscle glucose uptake $[64,65]$.

3.4. Aging: Adiponectin, Tumor Necrosis Factor Alpha, and Insulin-Like Growth Factor-1. Two strong correlates of aging and insulin-resistance include adiponectin and tumor necrosis factor alpha (TNF- $\alpha$ ), with low concentrations of adiponectin and high concentrations of TNF- $\alpha$ being linked to insulin-resistance $[43,73-75]$. Both may also play a role in body fat distribution $[37,43,44,76,77]$ and sarcopenia [18]. Adiponectin is secreted by adipose tissue (i.e., an adipokine) and is a key modulator of insulin sensitivity $[43,75,78]$ ). Low plasma adiponectin concentrations are associated with insulin-resistance, diabetes, obesity, body fat percentage, body fat distribution, and BMI [37, 43, 76, 79-82]. Adiponectin is believed to activate $5^{\prime}$-AMP-activated protein kinase (AMPK), which activates insulin-independent glucose uptake by the muscle, downregulates gluconeogenic enzymes and increases muscle fatty acid oxidation [83].

Tumor necrosis factor alpha (TNF- $\alpha$ ) is an inflammatory cytokine secreted by adipose tissue, macrophages, and other cells, which appears to influence insulin-resistance. Elevated TNF- $\alpha$ concentrations are linked to obesity and insulinresistance, while obese mice lacking TNF- $\alpha$ are protected from insulin-resistance [84]. Inflammatory pathways that impair insulin signaling at the level of IRS proteins are activated in the presence of TNF- $\alpha[73,84]$. TNF- $\alpha$ is correlated with body fat distribution [77] and sarcopenia [18] which may also lead to insulin-resistance among individuals with elevated TNF- $\alpha$ concentrations.

Unlike adiponectin and TNF- $\alpha$, insulin-like growth factor-I (ILGF-I) is not secreted by adipose tissue, but instead a peptide hormone which possesses insulin-like properties such as the promotion of glucose uptake by peripheral tissues $[85,86]$. Insulin-like growth factor-I concentrations decline with age, and is associated with the age-related changes in body composition by both increasing fat mass and decreasing muscle mass [87-89], thus potentially being a modulator of insulin-resistance. Administration of recombinant ILGF-I improves glucose uptake in those with insulin-resistance and type 2 diabetes. Other factors may be involved in the role of ILGF-I and glucose metabolism including binding proteins, hybrid receptors, and growth hormone secretion [90].

\section{Resistance Training: Influence on Insulin Resistance}

The diabetes prevention program (DPP) demonstrated that lifestyle modification reduces the development of diabetes by focusing on weight loss, increased physical activity, and dietary modification. Lifestyle modification decreased the incidence of type 2 diabetes by $58 \%$, as compared to the $31 \%$ among individuals taking metformin [91]. The physical activity component of the DPP recommended that individuals accumulate 150 minutes/week of moderate physical activity. The DPP stressed brisk walking as the physical activity of choice, but also lists aerobic dance, skating, bicycle riding, and swimming as options [91]. In support of the DPP's recommendations for aerobic training (AT), regular AT improves glucose control and insulin sensitivity [92, 93]. The American Diabetes Association (ADA) recommends that individuals with diabetes perform at least 150 minutes of moderateintensity AT per week [94]. However, factors such as obesity, arthritis, low back pain, and physical disabilities affecting many older adults may preclude this population from regularly performing AT [95-97]. Environmental factors such as unsafe neighborhoods or streets also may discourage engagement in many types of aerobic activity [97]. Therefore, alternative approaches for increasing physical activity among older adults should be considered.

Resistance training is one such alternative that can be safe and effective for older adults, including the elderly $[95,98-102]$. The ADA encourages individuals with type 2 diabetes to perform resistance exercise three times a week targeting all major muscle groups, progressing to three sets of $8-10$ repetitions at high intensity [103]. By using machines that provide external resistance with controlled movements, even those confined to a wheel chair or a walker can perform some types of RT. Though older adults demonstrate reduced overall muscle protein synthesis (MPS) relative to younger adults after a bout of resistance training [104], clinical trials investigating RT interventions among older adults have shown improvements in insulin-resistance and sarcopenia, by increasing lean body mass [19-31].

To identify published research relevant to the focus of this paper, a literature search was conducted using the PubMed search engine, developed by the US National Library of Medicine of the National Institutes of Health, without restrictions on publication date. Additional inclusion criteria 
were as follows: randomized controlled trial study design, studies conducted in middle-aged and older adults, study duration greater than one month. Intervention studies which met inclusion criteria are described in Table 1. Of the RT intervention studies reviewed, most reported improvements in glucose uptake, and reduced diabetes risk (i.e., 4 of 5 interventions report beneficial effects of RT on diabetesrelated outcomes). Intensity appears to influence the magnitude of improvement in these outcomes; high intensity RT (defined as training loads above $75 \%$ one-repetition maximum (RM) [105]) produces greater improvements than RT performed at a moderate or low intensity (training loads between $50 \%-74 \%$ of one RM and below $50 \%$ one RM, respectively [105]) [102, 106]. Although AT has been an accepted (see DPP [91]) and recommended (ADA $[94,103]$ ) exercise intervention to improve glucose metabolism, some investigations of the combined effects of RT and AT conclude that RT + AT exercise programs enhance diabetes related outcomes [23, 30], while others have suggested that RTalone programs have benefits comparable to that of AT-alone programs [22, 107-109]. Evidence to support one mode of training (RT versus AT) over the other is limited and should be further investigated before conclusions can be made as to the superiority of one form of exercise over the other.

Two RT modes were used in the five investigations included in Table 1. Four interventions utilized weighttraining machines $[27,31,79,109]$ while one used therabands [110]. Interestingly, all four studies using a weight-training machine protocol reported improvements in diabetes-related measures, whereas the RT intervention utilizing therabands did not lead to differences between exercise and control groups. The number of studies in this area is limited, yet these findings suggest that RT mode may be an important issue with regard to improvements in glucose metabolism.

Although Table 1 only includes studies investigating chronic RT effects, others have investigated glucose metabolism with acute bouts of RT, and reported conflicting results. Black et al. found that a single RT session performed at either low or high intensity, using either a multiple set or single set protocol, improved 24-hour postexercise insulin sensitivity measured via fasting plasma glucose [106]. Conversely, Jimenez et al. assessed insulin sensitivity using the euglycemic-hyperinsulinemic-clamp technique preexercise, and 12 and 36 hours postexercise, and reported no differences between control and exercise groups [111]. Methodological difference may have contributed to the conflicting findings (i.e., RT protocol, outcome measures, study population). Thus it remains uncertain the extent to which improvements in glucose/insulin metabolism with RT could be attributed to an acute exercise bout versus a result of chronic training.

4.1. Resistance Training: Changes in Insulin Signaling, Adiponectin, TNF- $\alpha$, and ILGF-1. Resistance-trained muscle has shown increased rates of insulin-stimulated glucose uptake and transport $[112,113]$. This has been attributed to the fact that RT increases aspects of the insulin signaling cascade that result in the upregulation of this pathway. Increases in the protein content of the insulin receptor and kinase activity (PIP-3, Akt/PKB, aPKC) are evident in resistance-trained muscle, even without increases in lean mass, and may enhance glucose uptake [96, 112-114]. Akt/PKB, insulin receptor protein, and glycogen synthase activity are increased with RT, all of which are downstream targets in the insulin signaling cascade that may be important in the translocation of GLUT-4 receptors and skeletal muscle glucose uptake [96]. These changes in the insulin signaling cascade are observed even without increases in lean mass [96]. In addition to (or possibly as a result of) the increased activity of the insulin signaling cascade, an increase in GLUT-4 protein concentration has also been observed with RT in humans [96] and rodents [112-114]. Thus, the two possible insulin signaling defects that result in insulin-resistance (decreased number of GLUT4 transporters and/or post receptor default in the insulin signaling cascade resulting in less GLUT-4 translocation) appear to be improved with RT. Increased insulin signaling activity, along with increases in GLUT-4 protein expression, may lead to increased GLUT-4 translocation thereby increasing glucose transport and reducing insulinresistance.

Improvements in adiponectin concentrations have been reported with weight loss [115-117], aerobic exercise [78, $80-82,118]$ and RT $[119,120]$. Since low adiponectin concentrations are associated with obesity, interventions often include weight loss to promote increases in adiponectin. However, some exercise interventions report increases in serum adiponectin concentrations without changes in body weight [20], although others do not [121]. There is also conflicting data on the influence of RT on adiponectin concentrations; some have reported no change $[79,116,122]$ while others have reported increases [119, 120]. Methodological differences (i.e., RT intensity, measurement of total versus low/high molecular weight adiponectin) may explain conflicting findings. With regard to TNF- $\alpha$, high intensity RT appears to reduce TNF- $\alpha$ concentrations and improve insulin sensitivity $[20,123,124]$, even when fat mass is unchanged [20].

There is conflicting data on the influence of RT on ILGF-I concentrations. Borst et al. reported that 25 weeks of 1 or 3-set resistance training increased ILGF-I in healthy adults aged 25 to 50 [125]; however, this was not observed in a subsequent study by the same group using adults aged 60-85 years and high and low-intensity resistance training [126]. Conversely, others have reported significant increases in ILGF-I with resistance training in the elderly $[99,127]$. These studies concluded that despite atrophy and ultrastructural damage, elders respond to RT with significant increases in musculoskeletal remodeling, cross-sectional area and elevated IGF-I levels [99, 127]. Increases in ILGF-I concentration are also associated with increases in lean mass, indicating that ILGF-I may be important in addressing agerelated sarcopenia and insulin-resistance. Although more research is needed in this area, it appears that ILGF-I concentrations can be increased in older adults to augment glucose uptake and improve insulin-resistance. 
TABLE 1: Randomized controlled trials $>1$ month in duration investigating the effect of resistance training on diabetes-related outcomes among nondiabetic middle-aged and older adults ${ }^{\dagger}$.

\begin{tabular}{|c|c|c|c|c|c|}
\hline Source & Study design & $\begin{array}{l}\text { Study } \\
\text { duration }\end{array}$ & RT protocol & Study population & Primary findings \\
\hline \multicolumn{6}{|c|}{ Traditional Weight Training only* } \\
\hline Iglay et al. [27] & $\begin{array}{l}\text { RCT }(n=36): \\
\mathrm{RT}+0.9 / \mathrm{g} / \mathrm{kg} / \mathrm{d} \\
\text { protein intake, } \\
n=16 \\
\mathrm{RT}+1.2 \mathrm{~g} / \mathrm{kg} / \mathrm{d} \\
n=16\end{array}$ & 3 months & $\begin{array}{l}3 \mathrm{x} \text { week, } 8 \text { machine } \\
\text { exercises, } 2 \text { sets } 8 \text { reps }+ \\
\text { one set to voluntary fatigue } \\
\text { at high intensity }\end{array}$ & $\begin{array}{l}\text { Healthy individuals, } \\
\text { aged } 60-62 \text { yrs. }\end{array}$ & $\begin{array}{l}\downarrow \text { glucose OGTT AUC } 25-28 \% \\
\text { with RT, no differences between } \\
\text { diet groups. }\end{array}$ \\
\hline $\begin{array}{l}\text { Onambélé- } \\
\text { Pearson et al. } \\
{[110]}\end{array}$ & $\begin{array}{l}\text { RCT }(n=30): \\
\text { LI }(\sim 40 \% 1 \mathrm{RM}) \\
n=18 \\
\text { HI }(\sim 80 \% 1 \mathrm{RM}) \\
n=12\end{array}$ & 3 months & $\begin{array}{l}\text { 3x week, } 6 \text { exercises using } \\
\text { therabands, progressing } \\
\text { from } 8-11 \text { reps and } 2-4 \\
\text { sets, different intensity } \\
\text { groups: HI versus LI }\end{array}$ & $\begin{array}{l}\text { Sedentary individuals, } \\
\text { aged } 55-80 \text { yrs. }\end{array}$ & $\begin{array}{l}\uparrow \text { fasting plasma glucose }(4.8 \pm \\
0.19 \text { to } 5.51 \pm 0.08 \mathrm{mmol} / \mathrm{L}) \text { in } \\
\text { HI group, no change in plasma } \\
\text { glucose for LI, no change in } \\
\text { plasma insulin for either group. }\end{array}$ \\
\hline $\begin{array}{l}\text { Zachwieja et al. } \\
\text { [31] }\end{array}$ & $\begin{array}{l}\text { RCT }(n=15): \\
\text { RT }+ \text { GH } \\
\text { injections, } \\
n=6 \\
\text { RT only, } n=9\end{array}$ & 4 months & $\begin{array}{l}4 \mathrm{x} \text { week, } 9 \text { machine } \\
\text { exercises, } 4 \text { sets, } 4-10 \text { reps } \\
\text { at high intensity. }\end{array}$ & $\begin{array}{l}\text { Healthy men, aged } \\
64-75 \text { yrs. }\end{array}$ & $\begin{array}{l}\uparrow \text { in glucose disappearance rate } \\
(3.0 \pm 0.3 \text { to } 4.0 \pm \\
0.4 \mathrm{mg} / 100 \mathrm{~mL} / \mathrm{min} \text { minimal } \\
\text { model of glucose kinetics, } \\
\text { IVGTT) with RT only }\end{array}$ \\
\hline \multicolumn{6}{|c|}{ RT + AT (either alone or combined) } \\
\hline $\begin{array}{l}\text { Ahmadizad et al. } \\
\text { [79] }\end{array}$ & $\begin{array}{l}\text { RCT }(n=24) \\
\text { AT, } n=8 \\
\text { RT, } n=8 \\
\text { Control, } n=8\end{array}$ & 3 months & $\begin{array}{l}3 \mathrm{x} \text { week, circuit weight } \\
\text { training, } 11 \text { machine } \\
\text { exercises, } 4 \text { sets, } 12 \text { reps, at } \\
\text { moderate intensity with } \\
30 \text { sec. rest between } \\
\text { exercises. }\end{array}$ & $\begin{array}{l}\text { Healthy men, aged } \\
35-48 \text { yrs. }\end{array}$ & $\begin{array}{l}\downarrow \text { HOMA-IR } 35.7 \text { and } 38.5 \% \\
\text { after AT and RT respectfully; no } \\
\text { differences between groups. }\end{array}$ \\
\hline $\begin{array}{l}\text { Smutok et al. } \\
\text { [109] }\end{array}$ & $\begin{array}{l}\text { RCT }(n=37): \\
\text { RT, } n=14 \\
\text { AT, } n=13 \\
\text { Control, } n=10\end{array}$ & $\begin{array}{l}4.5 \\
\text { months }\end{array}$ & $\begin{array}{l}3 \mathrm{x} \text { week, } 11 \text { machine } \\
\text { exercises, } 2 \text { sets, } 12-15 \text { reps } \\
\text { at moderate intensity. }\end{array}$ & $\begin{array}{l}\text { Men at risk for CHD } \\
\text { with either abnormal } \\
\text { glucose tolerance, } \\
\text { dyslipidemia, or } \\
\text { hypertension, aged } \\
\text { 41-59 yrs. }\end{array}$ & $\begin{array}{l}\downarrow \text { plasma glucose at } 60,90 \text {, and } \\
120 \text { minutes after glucose } \\
\text { ingestion with RT; } \downarrow \text { plasma } \\
\text { glucose at } 90 \text { and } 120 \text { min after } \\
\text { glucose ingestion with AT. } \downarrow \\
\text { fasting glucose with RT, no } \\
\text { changes with AT. Insulin OGTT } \\
\text { AUC } \downarrow 24 \% \text { for AT and } 21 \% \text { for } \\
\text { RT, no changes in control. }\end{array}$ \\
\hline
\end{tabular}

${ }^{*}$ Traditional Weight Training= any muscle strengthening exercises using resistance training machines/equipment, free weights (e.g., dumbbell, barbell) or therabands.

${ }^{\dagger}$ Abbreviations used: AT: Aerobic training, AUC: Area under curve, GH: Growth Hormone, HI: High intensity, HOMA: Homeostasis model assessment, IVGTT: Intravenous glucose tolerance test, IR: Insulin Resistance, LI: Low intensity, OGTT: Oral glucose tolerance test, Reps: Repetitions, RCT: Randomized controlled trial, RT: Resistance training.

4.2. Resistance Training and Body Fat Distribution. Body fat distribution may play a major role in the development of insulin-resistance, particularly abdominal fat [33, 42]. Resistance training reduces abdominal fat, including visceral fat, among individuals with diabetes $[116,128,129]$. Both low intensity RT three times per week [128], and high intensity RT twice per week [116] improve insulin-resistance and reduce body fat mass. Strength training-induced changes in abdominal visceral fat were also reported without significant weight loss [129]. Thus, RT alone may reduce abdominal and visceral fat, which is known to increase with advancing age and influence insulin-resistance.

An overview of how RT may influence age-related physiological changes impacting diabetes risk is presented graphically in Figure 1.

\section{Current Recommendations: Aging, Resistance Training, and Diabetes Prevention}

Major health organizations such as the American College of Sports Medicine (ACSM), American Heart Association (AHA), and the American Geriatrics Society (AGS) have issued recommendations regarding RT for older or diabetic individuals. As stated previously, the ADA encourages individuals with type 2 diabetes to perform resistance exercise three times per week targeting all major muscle groups, and progressing to three sets of 8-10 repetitions at high intensity [103]. According to the ACSM, older adults should engage in RT at least twice per week. These sessions should include 8-10 exercises of 8-12 repetitions, involving the major muscle groups, done at a moderate 


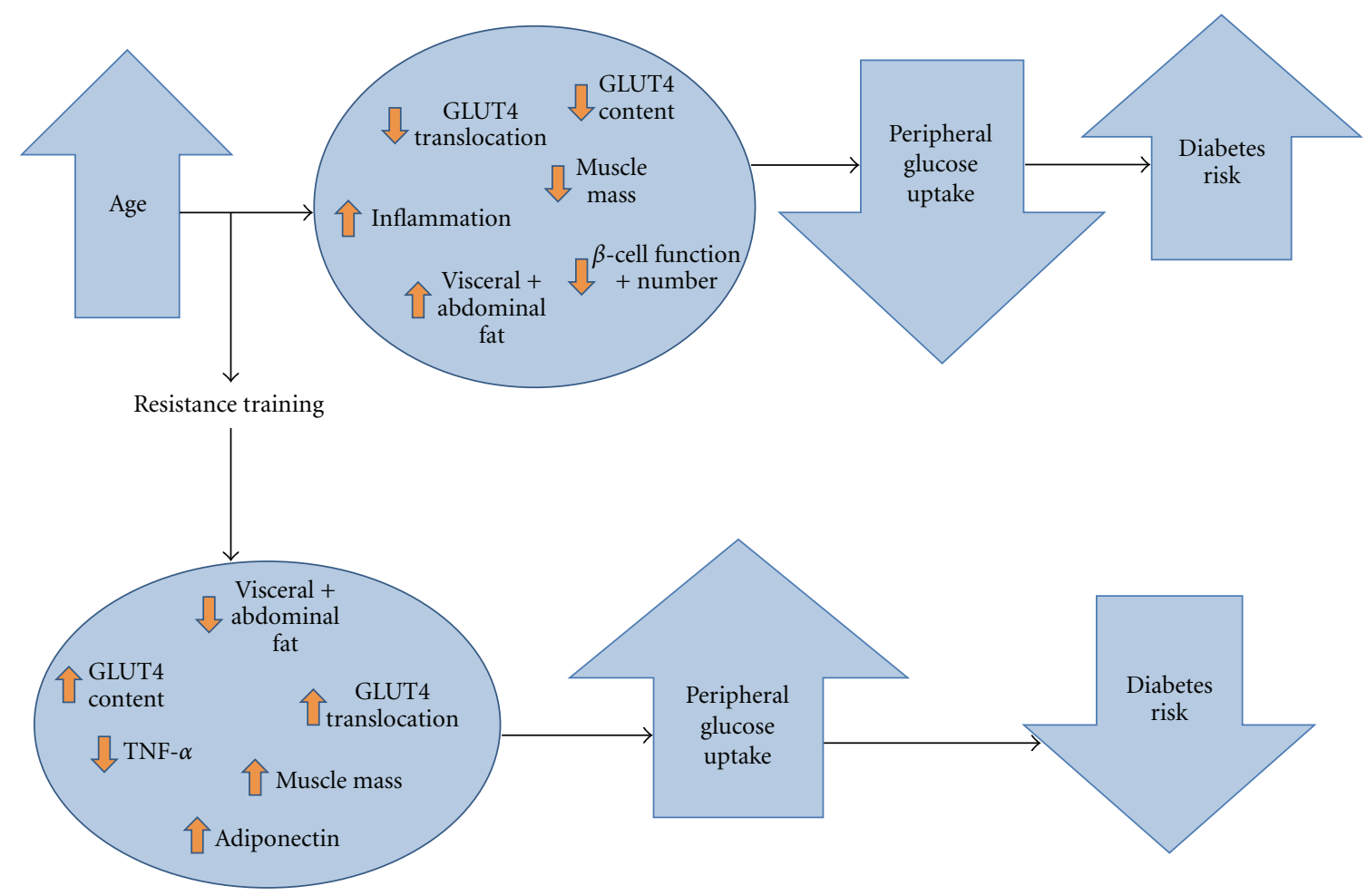

FIGURE 1: Age-related physiological changes and diabetes risk: Potential influence of RT.

to vigorous intensity [130]. Similarly, ACSM's position stand on exercise prescription for diabetes care recommends that individuals engage in RT at least twice per week, with 8-10 exercise involving the major muscle groups to be performed with at least one set of 10-15 repetitions. This position stand recognizes that increased intensity of exercise or adding additional sets may produce greater benefits, but may not be appropriate for some individuals [131]. Both ACSM position stands advocate progressive RT, with increases in resistance as the individual progresses through the program $[130,131]$. The AGS recommends 2-3 days per week of RT with 10-15 repetitions at low intensity, 8-10 at moderate intensity, or 6-8 at high intensity [132]. The AHA recommends that older adults engage in resistance training 2-3 nonconsecutive days per week doing one set of 10-15 repetitions at low intensity, and also recognizes that multiple set regimens performed at higher intensities and frequencies ( $>2$ days a week) may provide greater benefits [133]. These recommendations are similar to protocols used in many clinical trials investigating the effect of RT on diabetes-related outcomes among older adults (see Table 1). Two of the four trials included in Table 1 used a high intensity protocol, while 2 used moderate intensities and one had high intensity and low intensity groups. All of the studies used multiple set protocols. Frequency of training was most commonly three days per week $(n=4)$, while one study used a 4 day per week protocol.

Some studies have addressed the issue of RT intensity and volume on insulin sensitivity. High-intensity protocols show significant increases in insulin sensitivity as compared with moderate intensity protocols [106], and single set protocols may be less effective than multiple set protocols in lowering fasting blood glucose concentrations [106]. A meta analysis concluded that high intensity protocols were more effective than low intensity protocols at increasing strength in older adults [102]. Higher volume interventions are also associated with greater increases in lean body mass in older individuals [134] as well as young men [135]. This suggests the possibility of a dose-response relationship, such that improvements in strength and insulin-resistance are increased as RT intensity and volume increase. Additionally, others have reported that twice weekly RT at low intensity but high volume (three sets of ten repetitions) improved insulin-resistance [136]. Recently, RT interventions stressing volitional fatigue (i.e., the point at which the exercise could not be completed with proper technique) have been conducted [137, 138]; more work is needed to determine if this RT approach is beneficial with respect to blood glucose control and insulin-resistance.

Taken together, existing recommendations and these research studies suggest that high volume and high intensity RT may produce greater improvements in muscle mass gains, insulin-resistance and glucose tolerance; however, it would be prudent for sedentary older diabetic or prediabetic individuals to begin an RT program at low intensity (rate of perceived exertion of $\sim 5-6$ ) and low volume (1 set per exercise, 10-12 reps) twice weekly, and if time and fitness are sufficient, progressively increasing intensity, volume, and frequency $[130,131,133]$. 
5.1. Future Directions. Research suggests that RT may play a role in improving the age-related increases in insulinresistance, and prevent the onset of diabetes. Major health organizations have recognized the benefits of RT. However, according to the CDC, only $13 \%$ of men and less than $10 \%$ of woman aged $\geq 65 \mathrm{yrs}$ reported engaging in strength training at least two days per week [139]. Possible reasons for low rates of adoption and minimal adherence may include barriers such as the perceived complexity and knowledge needed to perform RT, misinformation of expected RT outcomes (e.g., excessive or undesirable hypertrophy), and the emphasis many public health programs and clinicians place on AT rather than RT. Once effective RT interventions are identified, the translational capabilities of intervention approaches should be investigated. Adherence, simplicity, and cost effectiveness are important for RT interventions to be successful in real-world settings.

Differences in traditional RT versus circuit weight training have not been addressed, as well as differences in protocols using free weights and those using machine weights. It is possible that certain $\mathrm{RT}$ approaches lead to greater rates of adoption, adherence and greater cost effectiveness among older, insulin resistant individuals.

Dietary and weight loss interventions in conjunction with RT should be investigated to determine the optimal approach for diabetes prevention with advancing age. For example, the role dietary protein intake may play in reversing insulin-resistance and improving glucose control should be studied more in depth, as high protein diets improve glucose control in individuals with type 2 diabetes when compared to those on a low protein diet $[140,141]$. Additionally, a positive relationship between protein intake and change in whole body fat-free mass has been observed after pooling RT studies investigating protein intake in adults aged 50-80 [142]. Based upon these findings, it has been suggested that the RDA for protein intake $(0.8 \mathrm{~g} / \mathrm{kg})$ is inadequate for older adults who engage in RT [142]. With the possibility that high protein diets can be beneficial to those with impairments in glucose metabolism as well as older adults engaging in RT, the synergistic effect of RT and high protein diets on glucose tolerance warrants further investigation.

Finally, additional work should be done to address mechanisms for RT-induced improvements in insulin-resistance and glucose tolerance. The specific effects of RT on insulin signaling are uncertain, and the effect of RT on pancreatic $\beta$-cell function/mass and mitochondrial dysfunction are unknown. It is also possible that other inflammatory markers not yet identified may influence sarcopenia and the response to RT among older adults. Although some work has been done addressing the effect of RT on visceral adipose tissue [76, 77], direct effects on FFA concentrations and gluconeogenesis are uncertain. By continuing to identify the mechanisms by which RT improves insulin-resistance, and by determining optimal combinations of RT with other lifestyle factors to prevent diabetes, interventions can be developed which optimize reduction in diabetes risk with advancing age.

In conclusion, it appears RT may be an effective intervention approach for middle-aged and older adults to counteract age-associated declines in insulin sensitivity and to prevent the onset of type 2 diabetes. Older adults who engage in RT may see benefits with respect to improvements in body composition, body fat distribution, inflammatory markers, and blood glucose homeostasis. Future research investigating mechanisms, optimal RT protocol, and intervention approaches with high translation potential are needed to enhance knowledge in this area, and to increase public awareness and adoption of RT.

\section{Acknowledgments}

This work was supported in part by K01KD075424 (to Brenda M. Davy) and R01DK082383 (to Brenda M. Davy and Richard A. Winett).

\section{References}

[1] Centers for Disease Control and Prevention, "Public health and aging: trends in aging-United States and worldwide," The Journal of the American Medical Association, vol. 289, no. 11, pp. 1371-1373, 2003.

[2] A. M. McBean, S. Li, D. T. Gilbertson, and A. J. Collins, "Differences in diabetes prevalence, incidence, and mortality among the elderly of four racial/ethnic groups: whites, blacks, Hispanics, and Asians," Diabetes Care, vol. 27, no. 10, pp. 2317-2324, 2004.

[3] T. Dall, S. E. Mann, Y. Zhang et al., "Economic costs of diabetes in the U.S. in 2007," Diabetes Care, vol. 31, no. 3, pp. 596-615, 2008.

[4] J. P. Boyle et al., "Projection of the year 2050 burden of diabetes in the US adult population: dynamic modeling of incidence, mortality, and prediabetes prevalence," Population Health Metrics, vol. 8, no. 1, p. 29, 2010.

[5] "Standards of medical care in diabetes-2009," Diabetes Care, vol. 32, supplement 1, pp. S13-S61, 2009.

[6] S. L. Norris, D. Kansagara, C. Bougatsos, and R. Fu, "Screening adults for type 2 diabetes: a review of the evidence for the U.S. preventive services task force," Annals of Internal Medicine, vol. 148, no. 11, pp. 855-868, 2008.

[7] E. L. M. Barr, P. Z. Zimmet, T. A. Welborn et al., "Risk of cardiovascular and all-cause mortality in individuals with diabetes mellitus, impaired fasting glucose, and impaired glucose tolerance: the Australian Diabetes, Obesity, and Lifestyle Study (AusDiab)," Circulation, vol. 116, no. 2, pp. 151-157, 2007.

[8] B. Strasser, U. Siebert, and W. Schobersberger, "Resistance training in the treatment of the metabolic syndrome: a systematic review and meta-analysis of the effect of resistance training on metabolic clustering in patients with abnormal glucose metabolism," Sports Medicine, vol. 40, no. 5, pp. 397$415,2010$.

[9] J. Lexell, C. C. Taylor, and M. Sjostrom, "What is the cause of the ageing atrophy? Total number, size and proportion of different fiber types studied in whole vastus lateralis muscle from 15- to 83-year-old men," Journal of the Neurological Sciences, vol. 84, no. 2-3, pp. 275-294, 1988.

[10] R. Roubenoff and C. Castaneda, "Sarcopenia-understanding the dynamics of aging muscle," Journal of the American Medical Association, vol. 286, no. 10, pp. 1230-1231, 2001.

[11] G. Percheron, J. Y. Hogrel, S. Denot-Ledunois et al., "Effect of 1-year oral administration of dehydroepiandrosterone 
to 60- to 80-year-old individuals on muscle function and cross-sectional area: a double-blind placebo-controlled trial," Archives of Internal Medicine, vol. 163, no. 6, pp. 720-727, 2003.

[12] C. Dutta and E. C. Hadley, "The significance of sarcopenia in old age," Journals of Gerontology A, Biological Sciences and Medical Sciences, vol. 50, pp. 1-4, 1995.

[13] L. J. Melton III, S. Khosla, C. S. Crowson, M. K. O'Connor, W. M. O'Fallon, and B. L. Riggs, "Epidemiology of sarcopenia," Journal of the American Geriatrics Society, vol. 48, no. 6, pp. 625-630, 2000.

[14] A. A. Sayer, H. E. Syddall, E. M. Dennison et al., "Grip strength and the metabolic syndrome: findings from the Hertfordshire Cohort Study," Quarterly Journal of Medicine, vol. 100, no. 11, pp. 707-713, 2007.

[15] J. Lexell, "Human aging, muscle mass, and fiber type composition," Journals of Gerontology A, Biological Sciences and Medical Sciences, vol. 50, pp. 11-16, 1995.

[16] A. A. Vandervoort, "Aging of the human neuromuscular system," Muscle and Nerve, vol. 25, no. 1, pp. 17-25, 2002.

[17] L. A. Burton and D. Sumukadas, "Optimal management of sarcopenia," Clinical Interventions in Aging, vol. 5, pp. 217228,2010 .

[18] G. L. Jensen, "Inflammation: roles in aging and sarcopenia," Journal of Parenteral and Enteral Nutrition, vol. 32, no. 6, pp. 656-659, 2008.

[19] J. C. Baldi and N. Snowling, "Resistance training improves glycaemic control in obese type 2 diabetic men," International Journal of Sports Medicine, vol. 24, no. 6, pp. 419-423, 2003.

[20] S. Balducci, S. Zanuso, A. Nicolucci et al., "Antiinflammatory effect of exercise training in subjects with type 2 diabetes and the metabolic syndrome is dependent on exercise modalities and independent of weight loss," Nutrition, Metabolism and Cardiovascular Diseases, vol. 20, no. 8, pp. 608-617, 2010.

[21] C. Castaneda, J. E. Layne, L. Munoz-Orians et al., "A randomized controlled trial of resistance exercise training to improve glycemic control in older adults with type 2 diabetes," Diabetes Care, vol. 25, no. 12, pp. 2335-2341, 2002.

[22] E. Cauza, U. Hanusch-Enserer, B. Strasser et al., "The relative benefits of endurance and strength training on the metabolic factors and muscle function of people with type 2 diabetes mellitus," Archives of Physical Medicine and Rehabilitation, vol. 86, no. 8, pp. 1527-1533, 2005.

[23] D. J. Cuff, G. S. Meneilly, A. Martin, A. Ignaszewski, H. D. Tildesley, and J. J. Frohlich, "Effective exercise modality to reduce insulin resistance in women with type 2 diabetes," Diabetes Care, vol. 26, no. 11, pp. 2977-2982, 2003.

[24] D. W. Dunstan, R. M. Daly, N. Owen et al., "Highintensity resistance training improves glycemic control in older patients with type 2 diabetes," Diabetes Care, vol. 25, no. 10, pp. 1729-1736, 2002.

[25] D. W. Dunstan, E. Vulikh, N. Owen, D. Jolley, J. Shaw, and P. Zimmet, "Community center-based resistance training for the maintenance of glycemic control in adults with type 2 diabetes," Diabetes Care, vol. 29, no. 12, pp. 2586-2591, 2006.

[26] L. M. Fenicchia, J. A. Kanaley, J. L. Azevedo et al., "Influence of resistance exercise training on glucose control in women with type 2 diabetes," Metabolism, vol. 53, no. 3, pp. 284-289, 2004.

[27] H. B. Iglay, J. P. Thyfault, J. W. Apolzan, and W. W. Campbell, "Resistance training and dietary protein: effects on glucose tolerance and contents of skeletal muscle insulin signaling proteins in older persons," American Journal of Clinical Nutrition, vol. 85, no. 4, pp. 1005-1013, 2007.
[28] T. Ishii, T. Yamakita, T. Sato, S. Tanaka, and S. Fujii, "Resistance training improves insulin sensitivity in NIDDM subjects without altering maximal oxygen uptake," Diabetes Care, vol. 21, no. 8, pp. 1353-1355, 1998.

[29] A. Maiorana, G. O’Driscoll, C. Goodman, R. Taylor, and D. Green, "Combined aerobic and resistance exercise improves glycemic control and fitness in type 2 diabetes," Diabetes Research and Clinical Practice, vol. 56, no. 2, pp. 115-123, 2002.

[30] R. J. Sigal, G. P. Kenny, N. G. Boule et al., "Effects of aerobic training, resistance training, or both on glycemic control in type 2 diabetes: a randomized trial," Annals of Internal Medicine, vol. 147, no. 6, pp. 357-369, 2007.

[31] J. J. Zachwieja, G. Toffolo, C. Cobelli, D. M. Bier, and K. E. Yarasheski, "Resistance exercise and growth hormone administration in older men: effects on insulin sensitivity and secretion during a stable-label intravenous glucose tolerance test," Metabolism, vol. 45, no. 2, pp. 254-260, 1996.

[32] J. L. Kuk, K. Kilpatrick, L. E. Davidson, R. Hudson, and R. Ross, "Whole-body skeletal muscle mass is not related to glucose tolerance or insulin sensitivity in overweight and obese men and women," Applied Physiology, Nutrition and Metabolism, vol. 33, no. 4, pp. 769-774, 2008.

[33] W. M. Kohrt, J. P. Kirwan, M. A. Staten, R. E. Bourey, D. S. King, and J. O. Holloszy, "Insulin resistance in aging is related to abdominal obesity," Diabetes, vol. 42, no. 2, pp. 273-281, 1993.

[34] C. Usui, M. Asaka, H. Kawano et al., "Visceral fat is a strong predictor of insulin resistance regardless of cardiorespiratory fitness in non-diabetic people," Journal of Nutritional Science and Vitaminology, vol. 56, no. 2, pp. 109-116, 2010.

[35] T. Douchi, S. Yamamoto, N. Yoshimitsu, T. Andoh, T. Matsuo, and Y. Nagata, "Relative contribution of aging and menopause to changes in lean and fat mass in segmental regions," Maturitas, vol. 42, no. 4, pp. 301-306, 2002.

[36] J. L. Kuk, T. J. Saunders, L. E. Davidson, and R. Ross, "Agerelated changes in total and regional fat distribution," Ageing Research Reviews, vol. 8, no. 4, pp. 339-348, 2009.

[37] E. Zoico, V. Di Francesco, G. Mazzali et al., "Adipocytokines, fat distribution, and insulin resistance in elderly men and women," Journals of Gerontology A, Biological Sciences and Medical Sciences, vol. 59, no. 9, pp. M935-M939, 2004.

[38] A. S. Ryan, "Insulin resistance with aging: effects of diet and exercise," Sports Medicine, vol. 30, no. 5, pp. 327-346, 2000.

[39] J. Stevens, J. Cai, E. R. Pamuk, D. F. Williamson, M. J. Thun, and J. L. Wood, "The effect of age on the association between body-mass index and mortality," New England Journal of Medicine, vol. 338, no. 1, pp. 1-7, 1998.

[40] K. M. Flegal, M. D. Carroll, C. L. Ogden, and L. R. Curtin, "Prevalence and trends in obesity among US adults, 19992008," Journal of the American Medical Association, vol. 303, no. 3, pp. 235-241, 2010.

[41] M. G. Davis and K. R. Fox, "Physical activity patterns assessed by accelerometry in older people," European Journal of Applied Physiology, vol. 100, no. 5, pp. 581-589, 2007.

[42] P. J. Coon, E. M. Rogus, D. Drinkwater, D. C. Muller, and A. P. Goldberg, "Role of body fat distribution in the decline in insulin sensitivity and glucose tolerance with age," Journal of Clinical Endocrinology and Metabolism, vol. 75, no. 4, pp. 1125-1132, 1992.

[43] M. Cnop, P. J. Havel, K. M. Utzschneider et al., "Relationship of adiponectin to body fat distribution, insulin sensitivity 
and plasma lipoproteins: evidence for independent roles of age and sex," Diabetologia, vol. 46, no. 4, pp. 459-469, 2003.

[44] G. Mazzali, V. Di Francesco, E. Zoico et al., "Interrelations between fat distribution, muscle lipid content, adipocytokines, and insulin resistance: effect of moderate weight loss in older women," American Journal of Clinical Nutrition, vol. 84, no. 5, pp. 1193-1199, 2006.

[45] S. Sandeep, K. Gokulakrishnan, K. Velmurugan, M. Deepa, and V. Mohan, "Visceral \& subcutaneous abdominal fat in relation to insulin resistance \& metabolic syndrome in nondiabetic south Indians," Indian Journal of Medical Research, vol. 131, no. 5, pp. 629-635, 2010.

[46] P. Bjorntorp, "'Portal' adipose tissue as a generator of risk factors for cardiovascular disease and diabetes," Arteriosclerosis, vol. 10, no. 4, pp. 493-496, 1990.

[47] S. Nielsen, Z. Guo, C. M. Johnson, D. D. Hensrud, and M. D. Jensen, "Splanchnic lipolysis in human obesity," Journal of Clinical Investigation, vol. 113, no. 11, pp. 1582-1588, 2004.

[48] M. D. Jensen, "Is visceral fat involved in the pathogenesis of the metabolic syndrome? Human model," Obesity, vol. 14, supplement 1, pp. 20S-24S, 2006.

[49] J. E. Galgani, C. Moro, and E. Ravussin, "Metabolic flexibility and insulin resistance," American Journal of Physiology, vol. 295, no. 5, pp. E1009-E1017, 2008.

[50] G. Bock, C. D. Man, M. Campioni et al., "Pathogenesis of pre-diabetes: mechanisms of fasting and postprandial hyperglycemia in people with impaired fasting glucose and/or impaired glucose tolerance," Diabetes, vol. 55, no. 12, pp. 3536-3549, 2006.

[51] M. S. Katz and D. T. Lowenthal, "Influences of age and exercise on glucose metabolism: implications for management of older diabetics," Southern Medical Journal, vol. 87, no. 5, pp. S70-S73, 1994.

[52] H. Shimokata, D. C. Muller, J. L. Fleg, J. Sorkin, A. W. Ziemba, and R. Andres, "Age as independent determinant of glucose tolerance," Diabetes, vol. 40, no. 1, pp. 44-51, 1991.

[53] M. J. Brady and A. R. Saltiel, "Closing in on the cause of insulin resistance and type 2 diabetes," Journal of Clinical Investigation, vol. 104, no. 6, pp. 675-676, 1999.

[54] A. Klip, "The many ways to regulate glucose transporter 4," Applied Physiology, Nutrition and Metabolism, vol. 34, no. 3, pp. 481-487, 2009.

[55] R. A. Jackson, P. M. Blix, and J. A. Matthews, "Influence of ageing on glucose homeostasis," Journal of Clinical Endocrinology and Metabolism, vol. 55, no. 5, pp. 840-848, 1982.

[56] R. I. Fink, P. Wallace, and J. M. Olefsky, "Effects of aging on glucose-mediated glucose disposal and glucose transport," Journal of Clinical Investigation, vol. 77, no. 6, pp. 2034-2041, 1986.

[57] R. H. Noth and E. L. Mazzaferri, "Age and the endocrine system," Clinics in Geriatric Medicine, vol. 1, no. 1, pp. 223 250, 1985.

[58] J. O. Holloszy, "Invited review: exercise-induced increase in muscle insulin sensitivity," Journal of Applied Physiology, vol. 99, no. 1, pp. 338-343, 2005.

[59] C. Skov-Jensen, M. Skovbro, A. Flint, J. W. Helge, and F. Dela, "Contraction-mediated glucose uptake is increased in men with impaired glucose tolerance," Applied Physiology, Nutrition and Metabolism, vol. 32, no. 1, pp. 115-124, 2007.

[60] E. Szoke, M. Z. Shrayyef, S. Messing et al., "Effect of aging on glucose homeostasis: accelerated deterioration of $\beta$-cell function in individuals with impaired glucose tolerance," Diabetes Care, vol. 31, no. 3, pp. 539-543, 2008.
[61] A. E. Butler, J. Janson, S. Bonner-Weir, R. Ritzel, R. A. Rizza, and P. C. Butler, " $\beta$-cell deficit and increased $\beta$-cell apoptosis in humans with type 2 diabetes," Diabetes, vol. 52, no. 1, pp. 102-110, 2003.

[62] K. Maedler, D. M. Schumann, F. Schulthess et al., "Aging correlates with decreased $\beta$-cell proliferative capacity and enhanced sensitivity to apoptosis: a potential role for fas and pancreatic duodenal homeobox-1," Diabetes, vol. 55, no. 9, pp. 2455-2462, 2006.

[63] T. W. Van Haeften, W. Pimenta, A. Mitrakou et al., "Relative contributions of $\beta$-cell function and tissue insulin sensitivity to fasting and postglucose-load glycemia," Metabolism, vol. 49, no. 10, pp. 1318-1325, 2000.

[64] J. A. Kim, Y. Wei, and J. R. Sowers, "Role of mitochondrial dysfunction in insulin resistance," Circulation Research, vol. 102, no. 4, pp. 401-414, 2008.

[65] M. A. Abdul-Ghani and R. A. DeFronzo, "Mitochondrial dysfunction, insulin resistance, and type 2 diabetes mellitus," Current Diabetes Reports, vol. 8, no. 3, pp. 173-178, 2008.

[66] K. F. Petersen, D. Befroy, S. Dufour et al., "Mitochondrial dysfunction in the elderly: possible role in insulin resistance," Science, vol. 300, no. 5622, pp. 1140-1142, 2003.

[67] R. Barazzoni, K. R. Short, and K. S. Nair, "Effects of aging on mitochondrial DNA copy number and cytochrome $\mathrm{c}$ oxidase gene expression in rat skeletal muscle, liver, and heart," Journal of Biological Chemistry, vol. 275, no. 5, pp. 3343-3347, 2000.

[68] G. A. Cortopassi, D. Shibata, N. W. Soong, and N. Arnheim, "A pattern of accumulation of a somatic deletion of mitochondrial DNA in aging human tissues," Proceedings of the National Academy of Sciences of the United States of America, vol. 89, no. 16, pp. 7370-7374, 1992.

[69] S. Sial, A. R. Coggan, R. Carroll, J. Goodwin, and S. Klein, "Fat and carbohydrate metabolism during exercise in elderly and young subjects," American Journal of Physiology, vol. 271, no. 6, part 1, pp. E983-E989, 1996.

[70] G. Perseghin, P. Scifo, F. De Cobelli et al., "Intramyocellular triglyceride content is a determinant of in vivo insulin resistance in humans: a $\mathrm{H}-\mathrm{C}$ nuclear magnetic resonance spectroscopy assessment in offspring of type 2 diabetic parents," Diabetes, vol. 48, no. 8, pp. 1600-1606, 1999.

[71] M. Krssak, K. Falk Petersen, A. Dresner et al., "Intramyocellular lipid concentrations are correlated with insulin sensitivity in humans: a H NMR spectroscopy study," Diabetologia, vol. 42, no. 1, pp. 113-116, 1999.

[72] M. E. Griffin, M. J. Marcucci, G. W. Cline et al., "Free fatty acid-induced insulin resistance is associated with activation of protein kinase $\mathrm{C} \theta$ and alterations in the insulin signaling cascade," Diabetes, vol. 48, no. 6, pp. 1270-1274, 2000.

[73] I. Nieto-Vazquez, S. Fernández-Veledo, D. K. Krämer, R. Vila-Bedmar, L. Garcia-Guerra, and M. Lorenzo, "Insulin resistance associated to obesity: the link TNF-alpha," Archives of Physiology and Biochemistry, vol. 114, no. 3, pp. 183-194, 2008.

[74] K. Rabe, M. Lehrke, K. G. Parhofer, and U. C. Broedl, "Adipokines and insulin resistance," Molecular Medicine, vol. 14, no. 11-12, pp. 741-751, 2008.

[75] U. B. Pajvani and P. E. Scherer, "Adiponectin: systemic contributor to insulin sensitivity," Current Diabetes Reports, vol. 3, no. 3, pp. 207-213, 2003.

[76] A. M. Kanaya, T. Harris, B. H. Goodpaster, F. Tylavsky, and S. R. Cummings, "Adipocytokines attenuate the association between visceral adiposity and diabetes in older adults," Diabetes Care, vol. 27, no. 6, pp. 1375-1380, 2004. 
[77] A. Koster, S. Stenholm, D. E. Alley et al., "Body fat distribution and inflammation among obese older adults with and without metabolic syndrome," Obesity, vol. 18, no. 12, pp. 2354-2361, 2010.

[78] S. Lim, H. C. Sung, IN. K. Jeong et al., "Insulin-sensitizing effects of exercise on adiponectin and retinol-binding protein-4 concentrations in young and middle-aged women," Journal of Clinical Endocrinology and Metabolism, vol. 93, no. 6, pp. 2263-2268, 2008.

[79] S. Ahmadizad, A. H. Haghighi, and M. R. Hamedinia, "Effects of resistance versus endurance training on serum adiponectin and insulin resistance index," European Journal of Endocrinology, vol. 157, no. 5, pp. 625-631, 2007.

[80] M. Blüher, C. J. Williams, N. Klöting et al., "Gene expression of adiponectin receptors in human visceral and subcutaneous adipose tissue is related to insulin resistance and metabolic parameters and is altered in response to physical training," Diabetes Care, vol. 30, no. 12, pp. 3110-3115, 2007.

[81] M. Blüher, J. W. Bullen, J. H. Lee et al., "Circulating adiponectin and expression of adiponectin receptors in human skeletal muscle: associations with metabolic parameters and insulin resistance and regulation by physical training," Journal of Clinical Endocrinology and Metabolism, vol. 91, no. 6, pp. 2310-2316, 2006.

[82] E. S. Kim, J.-A. Im, K. C. Kim et al., "Improved insulin sensitivity and adiponectin level after exercise training in obese Korean youth," Obesity, vol. 15, no. 12, pp. 3023-3030, 2007.

[83] T. Yamauchi, J. Kamon, Y. Minokoshi et al., "Adiponectin stimulates glucose utilization and fatty-acid oxidation by activating AMP-activated protein kinase," Nature Medicine, vol. 8, no. 11, pp. 1288-1295, 2002.

[84] G. S. Hotamisligil, "Inflammatory pathways and insulin action," International Journal of Obesity, vol. 27, supplement 3, pp. S53-S55, 2003.

[85] D. Le Roith, "Insulin-like growth factors," New England Journal of Medicine, vol. 336, no. 9, pp. 633-640, 1997.

[86] E. Rinderknecht and R. E. Humbel, "The amino acid sequence of human insulin-like growth factor I and its structural homology with proinsulin," Journal of Biological Chemistry, vol. 253, no. 8, pp. 2769-2776, 1978.

[87] C. A. Benbassat, K. C. Maki, and T. G. Unterman, "Circulating levels of insulin-like growth factor (IGF) binding protein- 1 and -3 in aging men: relationships to insulin, glucose, IGF, and dehydroepiandrosterone sulfate levels and anthropometric measures," Journal of Clinical Endocrinology and Metabolism, vol. 82, no. 5, pp. 1484-1491, 1997.

[88] E. Corpas, S. M. Harman, and M. R. Blackman, "Human growth hormone and human aging," Endocrine Reviews, vol. 14, no. 1, pp. 20-39, 1993.

[89] D. Rudman, A. G. Feller, H. S. Nagraj et al., "Effects of human growth hormone in men over 60 years old," New England Journal of Medicine, vol. 323, no. 1, pp. 1-6, 1990.

[90] S. N. Rajpathak, M. J. Gunter, J. Wylie-Rosett et al., "The role of insulin-like growth factor-I and its binding proteins in glucose homeostasis and type 2 diabetes," Diabetes/Metabolism Research and Reviews, vol. 25, no. 1, pp. 3-12, 2009.

[91] "The Diabetes Prevention Program (DPP): description of lifestyle intervention," Diabetes Care, vol. 25, no. 12, pp. 2165-2171, 2002.

[92] N. G. Boule, E. Haddad, G. P. Kenny, G. A. Wells, and R. J. Sigal, "Effects of exercise on glycemic control and body mass in type 2 diabetes mellitus: a meta-analysis of controlled clinical trials," Journal of the American Medical Association, vol. 286, no. 10, pp. 1218-1227, 2001.
[93] D. R. Dengel, R. E. Pratley, J. M. Hagberg, E. M. Rogus, and A. P. Goldberg, "Distinct effects of aerobic exercise training and weight loss on glucose homeostasis in obese sedentary men," Journal of Applied Physiology, vol. 81, no. 1, pp. 318325, 1996.

[94] R. J. Sigal, G. P. Kenny, D. H. Wasserman, C. CastanedaSceppa, and R. D. White, "Physical activity/exercise and type 2 diabetes: a consensus statement from the American Diabetes Association," Diabetes Care, vol. 29, no. 6, pp. 1433$1438,2006$.

[95] M. A. Fiatarone, E. F. O’Neill, N. D. Ryan et al., "Exercise training and nutritional supplementation for physical frailty in very elderly people," New England Journal of Medicine, vol. 330, no. 25, pp. 1769-1775, 1994.

[96] M. K. Holten, M. Zacho, M. Gaster, C. Juel, J. F. P. Wojtaszewski, and F. Dela, "Strength training increases insulinmediated glucose uptake, GLUT4 content, and insulin signaling in skeletal muscle in patients with type 2 diabetes," Diabetes, vol. 53, no. 2, pp. 294-305, 2004.

[97] M. Rantakokko, S. Iwarsson, M. Hirvensalo, R. Leinonen, E. Heikkinen, and T. Rantanen, "Unmet physical activity need in old age," Journal of the American Geriatrics Society, vol. 58, no. 4, pp. 707-712, 2010.

[98] O. Seynnes, M. A. F. Singh, O. Hue, P. Pras, P. Legros, and P. L. Bernard, "Physiological and functional responses to low-moderate versus high-intensity progressive resistance training in frail elders," Journals of Gerontology A, Biological Sciences and Medical Sciences, vol. 59, no. 5, pp. 503-509, 2004.

[99] M. A. Fiatarone Singh, W. Ding, T. J. Manfredi et al., "Insulinlike growth factor I in skeletal muscle after weight-lifting exercise in frail elders," American Journal of Physiology, vol. 277, no. 1, part 1, pp. E135-E143, 1999.

[100] N. A. Singh, K. M. Clements, and M. A. Fiatarone, "A randomized controlled trial of progressive resistance training in depressed elders," Journals of Gerontology A, Biological Sciences and Medical Sciences, vol. 52, no. 1, pp. M27-M35, 1997.

[101] B. F. Hurley, R. A. Redmond, R. E. Pratley, M. S. Treuth, M. A. Rogers, and A. P. Goldberg, "Effects of strength training on muscle hypertrophy and muscle cell disruption in elder men," International Journal of Sports Medicine, vol. 16, no. 6, pp. 378-384, 1995.

[102] S. Steib, D. Schoene, and K. Pfeifer, "Dose-response relationship of resistance training in older adults: a meta-analysis," Medicine and Science in Sports and Exercise, vol. 42, no. 5, pp. 902-914, 2010.

[103] "Standards of medical care in diabetes-2006," Diabetes Care, vol. 29, supplement 1, pp. S4-S42, 2006.

[104] V. Kumar, A. Selby, D. Rankin et al., "Age-related differences in the dose-response relationship of muscle protein synthesis to resistance exercise in young and old men," Journal of Physiology, vol. 587, no. 1, pp. 211-217, 2009.

[105] U.S. Department of Health and Human Sercices, C.f.D.C.a.P., National Center for Chronic Disease Prevention and Health Promotion, "U.S. Department of health and Human Services: Physical Activity and health: A Report of the Surgeon General," Atlanta, 1996.

[106] L. E. Black, P. D. Swan, and B. A. Alvar, "Effects of intensity and volume on insulin sensitivity during acute bouts of resistance training," Journal of Strength and Conditioning Research, vol. 24, no. 4, pp. 1109-1116, 2010.

[107] J. Eriksson, J. Tuominen, T. Valle et al., "Aerobic endurance exercise or circuit-type resistance training for individuals 
with impaired glucose tolerance?" Hormone and Metabolic Research, vol. 30, no. 1, pp. 37-41, 1998.

[108] M. A. Smutok, C. Reece, P. F. Kohhinos et al., "Effects of exercise training modality on glucose tolerance in men with abnormal glucose regulation," International Journal of Sports Medicine, vol. 15, no. 6, pp. 283-289, 1994.

[109] M. A. Smutok, C. Reece, P. F. Kokkinos et al., "Aerobic versus strength training for risk factor intervention in middle- aged men at high risk for coronary heart disease," Metabolism, vol. 42, no. 2, pp. 177-184, 1993.

[110] G. L. Onambélé-Pearson, L. Breen, and C. E. Stewart, "Influence of exercise intensity in older persons with unchanged habitual nutritional intake: skeletal muscle and endocrine adaptations," Age, vol. 32, no. 2, pp. 139-153, 2010.

[111] C. Jimenez, M. Santiago, M. Sitler, G. Boden, and C. Homko, "Insulin-sensitivity response to a single bout of resistive exercise in type 1 diabetes mellitus," Journal of Sport Rehabilitation, vol. 18, no. 4, pp. 564-571, 2009.

[112] B. B. Yaspelkis, "Resistance training improves insulin signaling and action in skeletal muscle," Exercise and Sport Sciences Reviews, vol. 34, no. 1, pp. 42-46, 2006.

[113] A. D. Krisan, D. E. Collins, A. M. Crain et al., "Resistance training enhances components of the insulin signaling cascade in normal and high-fat-fed rodent skeletal muscle," Journal of Applied Physiology, vol. 96, no. 5, pp. 1691-1700, 2004.

[114] B. B. Yaspelkis III, M. K. Singh, B. Trevino, A. D. Krisan, and D. E. Collins, "Resistance training increases glucose uptake and transport in rat skeletal muscle," Acta Physiologica Scandinavica, vol. 175, no. 4, pp. 315-323, 2002.

[115] C. J. Behre, A. Gummesson, M. Jernås et al., "Dissociation between adipose tissue expression and serum levels of adiponectin during and after diet-induced weight loss in obese subjects with and without the metabolic syndrome," Metabolism, vol. 56, no. 8, pp. 1022-1028, 2007.

[116] J. Ibanez, M. Izquierdo, C. Martínez-Labari et al., "Resistance training improves cardiovascular risk factors in obese women despite a significative decrease in serum adiponectin levels," Obesity, vol. 18, no. 3, pp. 535-541, 2010.

[117] E. P. Weiss, S. B. Racette, D. T. Villareal et al., "Improvements in glucose tolerance and insulin action induced by increasing energy expenditure or decreasing energy intake: a randomized controlled trial," American Journal of Clinical Nutrition, vol. 84, no. 5, pp. 1033-1042, 2006.

[118] A. Oberbach, A. Tönjes, N. Klöting et al., "Effect of a 4 week physical training program on plasma concentrations of inflammatory markers in patients with abnormal glucose tolerance," European Journal of Endocrinology, vol. 154, no. 4, pp. 577-585, 2006.

[119] I. G. Fatouros, A. Chatzinikolaou, S. Tournis et al., "Intensity of resistance exercise determines adipokine and resting energy expenditure responses in overweight elderly individuals," Diabetes Care, vol. 32, no. 12, pp. 2161-2167, 2009.

[120] N. Brooks, J. E. Layne, P. L. Gordon, R. Roubenoff, M. E. Nelson, and C. Castaneda-Sceppa, "Strength training improves muscle quality and insulin sensitivity in Hispanic older adults with type 2 diabetes," International Journal of Medical Sciences, vol. 4, no. 1, pp. 19-27, 2007.

[121] M. W. Hulver, D. Zheng, C. J. Tanner et al., "Adiponectin is not altered with exercise training despite enhanced insulin action," American Journal of Physiology, vol. 283, no. 4, pp. E861-E865, 2002.

[122] E. Klimcakova, J. Polak, C. Moro et al., "Dynamic strength training improves insulin sensitivity without altering plasma levels and gene expression of adipokines in subcutaneous adipose tissue in obese men," Journal of Clinical Endocrinology and Metabolism, vol. 91, no. 12, pp. 5107-5112, 2006.

[123] J. S. Greiwe, C. Bo, D. C. Rubin, K. E. Yarasheski, and C. F. Semenkovich, "Resistance exercise decreases skeletal muscle tumor necrosis factor $\alpha$ in frail elderly humans," FASEB Journal, vol. 15, no. 2, pp. 475-482, 2001.

[124] M. D. Phillips, M. G. Flynn, B. K. McFarlin, L. K. Stewart, and K. L. Timmerman, "Resistance training at eightrepetition maximum reduces the inflammatory milieu in elderly women," Medicine and Science in Sports and Exercise, vol. 42, no. 2, pp. 314-325, 2010.

[125] S. E. Borst, D. V. De Hoyos, L. Garzarella et al., "Effects of resistance training on insulin-like growth factor-I and IGF binding proteins," Medicine and Science in Sports and Exercise, vol. 33, no. 4, pp. 648-653, 2001.

[126] S. E. Borst, K. R. Vincent, D. T. Lowenthal, and R. W. Braith, "Effects of resistance training on insulin-like growth factor and its binding proteins in men and women aged 60 to 85," Journal of the American Geriatrics Society, vol. 50, no. 5, pp. 884-888, 2002.

[127] S. Bermon, P. Ferrari, P. Bernard, S. Altare, and C. Dolisi, "Responses of total and free insulin-like growth factor-I and insulin-like growth factor binding protein-3 after resistance exercise and training in elderly subjects," Acta Physiologica Scandinavica, vol. 165, no. 1, pp. 51-56, 1999.

[128] H. R. Kwon et al., "The effects of resistance training on muscle and body fat mass and muscle strength in type 2 diabetic women," Korean Diabetes Journal, vol. 34, no. 2, pp. 101-110, 2010.

[129] M. S. Treuth, G. R. Hunter, T. Kekes-Szabo, R. L. Weinsier, M. I. Goran, and L. Berland, "Reduction in intra-abdominal adipose tissue after strength training in older women," Journal of Applied Physiology, vol. 78, no. 4, pp. 1425-1431, 1995.

[130] W. J. Chodzko-Zajko et al., "American college of sports medicine position stand. Exercise and physical activity for older adults," Medicine \& Science in Sports \& Exercise, vol. 41, no. 7, pp. 1510-1530, 2009.

[131] A. Albright, M. Franz, G. Hornsby, A. Kriska, D. Marrero, and I. Ullrich, "ACSM position stand on exercise and type 2 diabetes," Medicine and Science in Sports and Exercise, vol. 32, no. 7, pp. 1345-1360, 2000.

[132] N. Lundebjerg, "Exercise prescription for older adults with osteoarthritis pain: consensus practice recommendations," Journal of the American Geriatrics Society, vol. 49, no. 6, pp. 808-823, 2001.

[133] M. A. Williams, W. L. Haskell, P. A. Ades et al., "Resistance exercise in individuals with and without cardiovascular disease: 2007 update: a scientific statement from the American Heart Association Council on Clinical Cardiology and Council on Nutrition, Physical Activity, and Metabolism," Circulation, vol. 116, no. 5, pp. 572-584, 2007.

[134] M. D. Peterson, A. Sen, and P. M. Gordon, "Influence of resistance exercise on lean body mass in aging adults: a metaanalysis," Medicine \& Science in Sports \& Exercise. In press.

[135] N. A. Burd, A. M. Holwerda, K. C. Selby et al., "Resistance exercise volume affects myofibrillar protein synthesis and anabolic signalling molecule phosphorylation in young men," Journal of Physiology, vol. 588, no. 16, pp. 3119-3130, 2010.

[136] S. Kodama, M. Shu, K. Saito et al., "Even low-intensity and low-volume exercise training may improve insulin resistance 
in the elderly," Internal Medicine, vol. 46, no. 14, pp. 10711077, 2007.

[137] N. A. Burd, D. W. D. West, A. W. Staples et al., "Low-load high volume resistance exercise stimulates muscle protein synthesis more than high-load low volume resistance exercise in young men," PLoS One, vol. 5, no. 8, p. 10, 2010.

[138] S. M. Phillips and R. A. Winett, "Uncomplicated resistance training and health-related outcomes: evidence for a public health mandate," Current Sports Medicine Reports, vol. 9, no. 4, pp. 208-213, 2010.

[139] Strength Training among adults aged $\geq 65$-United States, 2001, 2001.

[140] M. C. Gannon and F. Q. Nuttall, "Effect of a high-protein, low-carbohydrate diet on blood glucose control in people with type 2 diabetes," Diabetes, vol. 53, no. 9, pp. 2375-2382, 2004.

[141] M. C. Gannon, F. Q. Nuttall, A. Saeed, K. Jordan, and H. Hoover, "An increase in dietary protein improves the blood glucose response in persons with type 2 diabetes," American Journal of Clinical Nutrition, vol. 78, no. 4, pp. 734-741, 2003.

[142] W. W. Campbell and H. J. Leidy, "Dietary protein and resistance training effects on muscle and body composition in older persons," Journal of the American College of Nutrition, vol. 26, no. 6, pp. 696S-703S, 2007. 


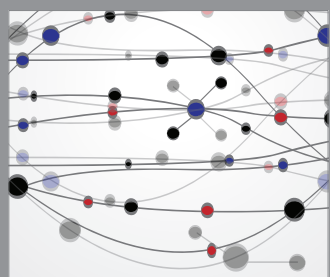

The Scientific World Journal
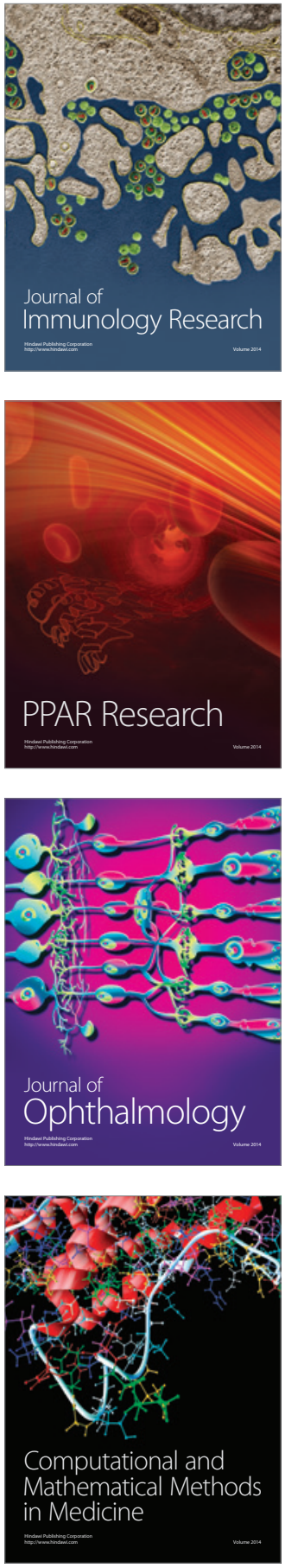

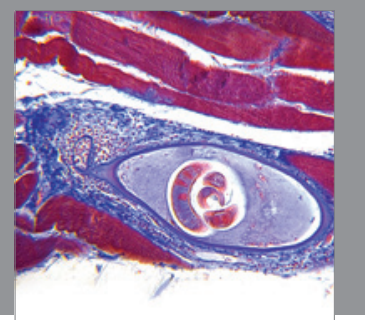

Gastroenterology

Research and Practice
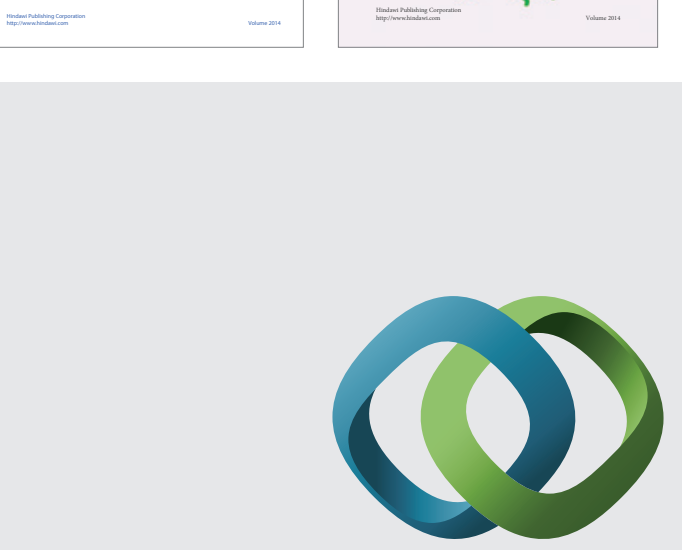

\section{Hindawi}

Submit your manuscripts at

http://www.hindawi.com
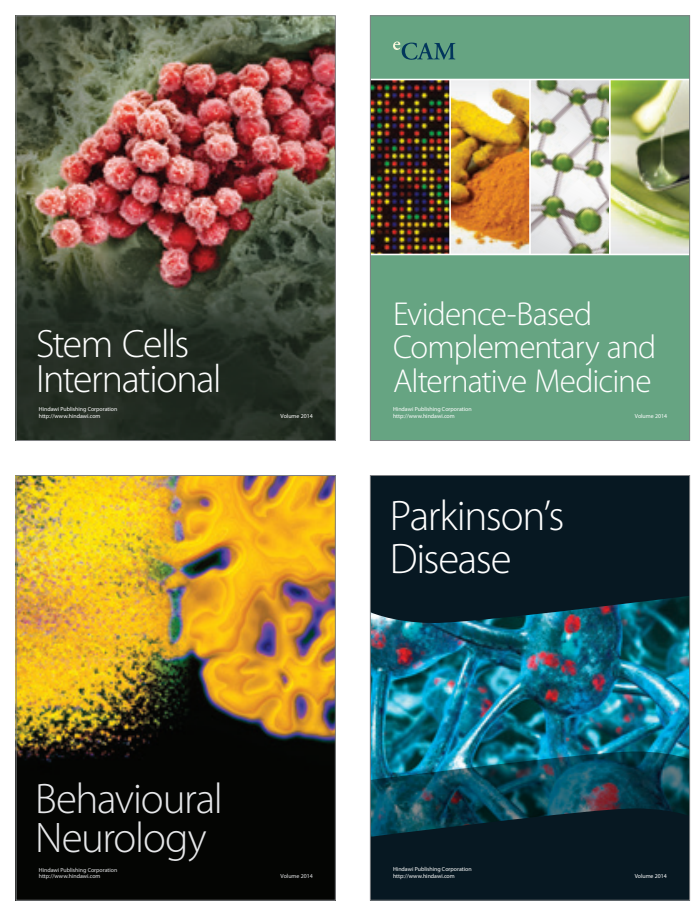

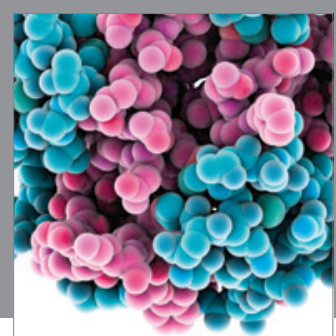

Journal of
Diabetes Research

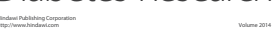

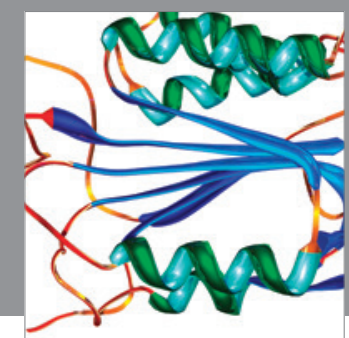

Disease Markers
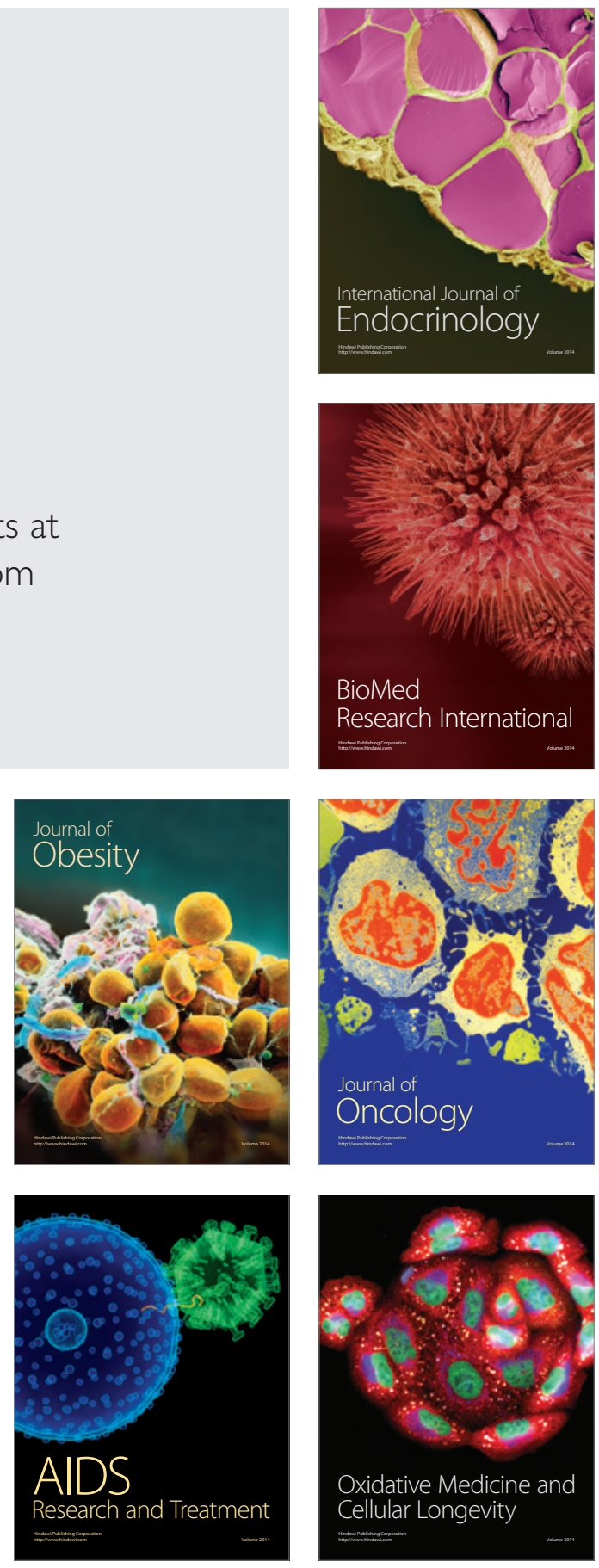